\title{
LETTERS
}

\section{Severe septicaemia in a patient with polychondritis and Sweet's syndrome after initiation of treatment with infliximab}

\author{
F G Matzkies, B Manger, M Schmitt-Haendle, T Nagel, H-G Kraetsch, J R Kalden, \\ H Schulze-Koops
}

Ann Rheum Dis 2003;62:81-82

$\mathrm{R}$ Sweet first described an acute febrile neutrophilic dermatosis in 1964 characterised by acute onset, fever, leucocytosis, and erythematous plaques. ${ }^{1}$ Skin biopsy specimens show infiltrates consisting of mononuclear cells and neutrophils with leucocytoclasis, but without signs of vasculitis. Sweet's syndrome is frequently associated with solid malignancies or haemoproliferative disorders, but associations with chronic autoimmune connective tissue disorders have also been reported. ${ }^{2}$ The aetiology of Sweet's syndrome is unknown, but evidence suggests that an immunological reaction of unknown specificity is the underlying mechanism.

\section{CASE REPORT}

A 51 year old white man with relapsing polychondritis (first diagnosed in 1997) was admitted to our hospital in June 2001 with a five week history of general malaise, fever, recurrent arthritis, and complaints of morning stiffness. Besides autoimmune polychondritis, he had insulin dependent diabetes mellitus that was diagnosed in 1989.

On admission, he presented with multiple small to medium, sharply demarked, raised erythematous plaques on both forearms and lower legs, multiple acne-like pustules on the face, neck, and chest, two abscesses on both thighs, and paronychia of several fingers. Microbiological examinations of the abscesses showed that they were sterile, and no bacterial or viral DNA was found in the acne-like lesions. Staphylococcus aureus was isolated from the finger paronychia. Laboratory testing showed a white blood cell count of $3.1 \times 10^{9} / 1$ with $40 \%$ lymphocytes and $46 \%$ neutrophils, a $\mathrm{C}$ reactive protein of $0.21 \mathrm{~g} / \mathrm{l}$ and maximally raised erythrocyte sedimentation rate. Surgical wound debridement was performed on the fingers and, because of immunosuppressive treatment (glucocorticoids, methotrexate, and azathioprine), systemic antibiotic treatment was started even in the absence of detectable systemic infection. Several days after admission, the patient developed an arthritis flare. Multiple skin biopsy samples were taken and showed typical features of Sweet's syndrome without signs of bacterial or viral infection.

As the patient had developed Sweet's syndrome while receiving immunosuppression and the underlying immunological activity of his polychondritis appeared to be insufficiently controlled, azathioprine was stopped and, in the absence of detectable infections, infliximab was used in an attempt to suppress the continuous (auto)immune reactivity.

Infliximab was given at $3 \mathrm{mg} / \mathrm{kg}$ body weight. Arthritis and morning stiffness rapidly resolved. The skin lesions disappeared and no new skin lesions developed. However, 14 days after the application, the patient developed fever of up to $40^{\circ} \mathrm{C}$ and new erythematous plaques, similar in appearance and location to the original plaques (fig 1). As at first admission, an infection was ruled out by intensive clinical, laboratory, microbiological, and radiological tests. Consequently, a higher

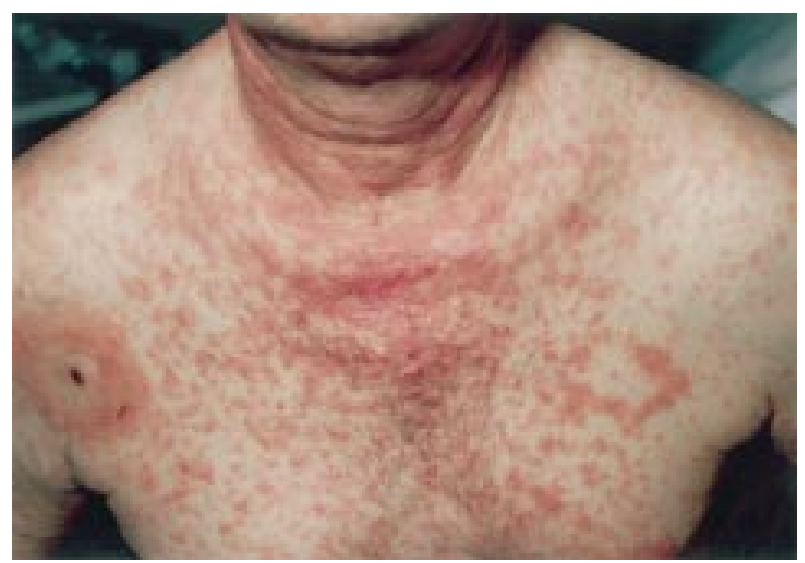

Figure 1 Manifestation of Sweet's syndrome in a patient with relapsing polychondritis.

dose of glucocorticoids (80 mg) and a second application of infliximab ( $3 \mathrm{mg} / \mathrm{kg}$ body weight) were given. The erythematous rash rapidly resolved and the patient was discharged from the hospital in apparently good health.

Eleven days after the second treatment with infliximab, the patient presented with myalgias, subfebrile temperatures, and general malaise. A parasternal abscess with connection into the mediastinum and new multiple pulmonal round formations were detected by computed tomography scan. Subsequently, the patient developed multiple abscesses on the right elbow and both feet. Penicillin resistant Staphylococcus aureus was isolated from the parasternal abscess. Despite systemic antibiotic treatment and surgical incisions, the patient deteriorated, developed pneumonia and rapidly met the criteria of septicaemia with acute renal and respiratory failure. Despite continuous aggressive wide range antibiotic and antimycotic treatment and maximum intensive care, he died of multiorgan failure as a consequence of progressive septicaemia. Shortly before his death, 11 weeks after the second infusion of infliximab, the typical Sweet's syndrome skin lesions reappeared.

\section{DISCUSSION}

Neutralising tumour necrosis factor $\alpha(\mathrm{TNF} \alpha)$ has been employed as a powerful anti-inflammatory principle in patients with rheumatoid arthritis and other rheumatic diseases such as Still's disease or giant cell arteritis. ${ }^{3-5}$ After several immunosuppressive drugs alone or in combination had failed to control immunological activity in our patient, infliximab was used and the clinical symptoms rapidly improved, leading to complete resolution of the arthritis, morning stiffness, and skin lesions. However, the case of our 
patient dramatically underlines the risk of infectious complications after neutralising $\mathrm{TNF}^{6}$ that might be particularly important in patients with a compromised immune system as a consequence of immunosuppressive drugs and/or diseases favouring infectious diseases, such as diabetes, as was the case here. The unfortunate course of our patient should alert rheumatologists to employ reagents that neutralise TNF $\alpha$ with extreme caution in patients who are more susceptible to infections because of accompanying diseases and/or concomitant immunosuppressive treatment.

\section{Authors' affiliations}

F G Matzkies, B Manger, M Schmitt-Haendle, T Nagel, H-G Kraetsch, J R Kalden, H Schulze-Koops, University of Erlangen-Nuremberg, Department of Internal Medicine III and Institute for Clinical Immunology, Krankenhausstrasse 12, 91054 Erlangen, Germany H Schulze-Koops, Nikolaus Fiebiger Centre for Molecular Medicine, Clinical Research Group III, University of Erlangen-Nuremberg,

Glueckstrasse 6, 91054 Erlangen, Germany
Correspondence to: Dr H Schulze-Koops, Nikolaus Fiebiger Centre for Molecular Medicine, Clinical Research Group III, University of Erlangen-Nuremberg, Glueckstrasse 6, 91054 Erlangen, Germany:

Schulze-Koops@med3.imed.uni-erlangen.de

Accepted 19 June 2002

\section{REFERENCES}

Sweet RD. Acute febrile neutrophilic dermatosis. Br J Dermatol 1964;76:349-53.

2 von den Driesch P. Sweet's syndrome (acute febrile neutrophilic dermatosis). J Am Acad Dermatol 1994;31:535-56.

3 Lipsky PE, van der Heijde DM, St Clair EW, Furst DE, Breedveld FC, Kalden JR, et al. Infliximab and methotrexate in the treatment of rheumatoid arthritis. Anti-Tumor Necrosis Factor Trial in Rheumatoid Arthritis with Concomitant Therapy Study. N Engl J Med 2000;343: 1594-602.

4 Kraetsch HG, Antoni C, Kalden JR, Manger B. Successful treatment of a small cohort of patients with adult onset of Still's disease with infliximab: first experiences. Ann Rheum Dis 2001;60(suppl III): iii55-7.

5 Cantini F Niccoli L, Salvarani C, Padula A, Olivieri I. Treatment of longstanding active giant cell arteritis with infliximab: report of four cases. Arthritis Rheum 2001:44:2933-5.

6 Keane J, Gershon S, Wise RP, Mirabile-Levens E, Kasznica J, Schwieterman WD, et al. Tuberculosis associated with infliximab, a tumor necrosis factor alpha-neutralizing agent. N Engl J Med 2001;345:1098-104.

\title{
Adrenomedullin in synovial fluids from patients with rheumatoid arthritis inhibits interleukin 6 production from synoviocytes
}

\author{
Y Nanke, S Kotake, K Yonemoto, S Saito, T Tomatsu, N Kamatani
}

A drenomedullin (AM) is a hypotensive peptide found in human pheochromocytoma tissue, which comprises 52 amino acids with an intramolecular disulphide bond. ${ }^{12}$ The ring structure and amidated C-terminus of AM are critical for its receptor binding and hypotensive activity. The mature AM is synthesised as glycine extended AM followed by C-terminal amidation to assume a biologically active form in tissues. AM has a vasorelaxant effect, antagonising the vasospastic effect of endothelin-1 (ET-1). Recently, proinflammatory cytokines, such as tumour necrosis factors $\alpha(\mathrm{TNF} \alpha)$ and interleukin-1 (ILl), were found to stimulate production and secretion of AM from vascular endothelial cells and vascular smooth muscle cells in vitro, suggesting that AM interacts with the immune system. ${ }^{3}$ However, AM reduces the

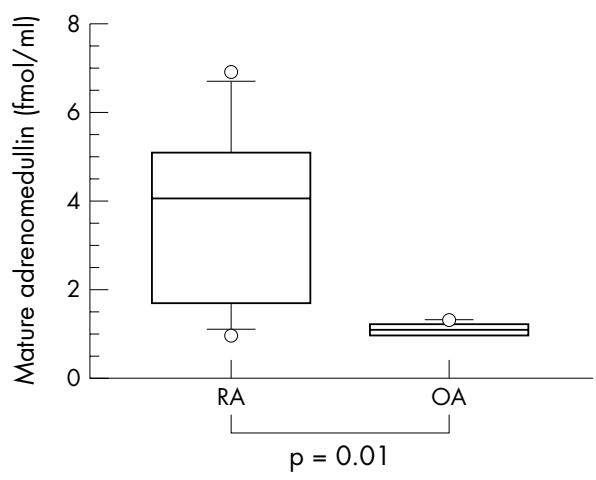

Figure 1 The concentration of mature $A M$ was higher in patients with RA than in those with $O A(p=0.01)$. Synovial fluids were obtained from nine patients with RA and six patients with OA. production of TNF $\alpha$ from macrophages stimulated with lipopolysaccharide. In addition, AM shows an antiinflammatory effect that reduces the production of the IL8 family by macrophages. ${ }^{4}$ We recently reported that the concentration of AM is raised in plasma from patients with systemic sclerosis complicated by pulmonary hypertension. ${ }^{5}$

Rheumatoid arthritis (RA) is a chronic inflammatory disease of unknown cause. Inflammatory cells and cytokines such as IL1, IL6, TNF $\alpha$, and IL17 are responsible, at least in part, for the pathological immune response in RA. ${ }^{6}$ Thus, we suggested that AM may play a part in the pathogenesis of RA.

Synovial fluids were obtained from nine patients with RA, and from six patients with osteoarthritis (OA). The concentrations of total and mature AM were measured by immunoradiometric assay. The level of ET-1 was measured by radioimmune assay. For the immunohistochemical studies, synovial tissue was obtained from the knees of three patients with RA and three with OA and stained using antihuman AM antibody and antihuman ET- 1 antibody.

To explore the effect of AM on the production of IL6 from RA synoviocytes, the synovial cells obtained from three patients with RA were cultured for eight days and AM was added at various concentrations for three days. The level of IL6 in the supernatant was measured by an enzyme immunoassay.

The concentration of total AM in synovial fluid (mean (SD); $\mathrm{pg} / \mathrm{ml}$ ) was significantly higher in patients with RA (31.4 (14.7) $\mathrm{pg} / \mathrm{ml}$ ) than in patients with OA (5.5 (1.7) $\mathrm{pg} / \mathrm{ml}$ $(p=0.001)$ (web extra fig Wl). The levels of mature AM were also higher in patients with RA $(3.7$ (2.1) fmol/l) than in patients with OA ( $1.1(0.2) \mathrm{fmol} / \mathrm{l})(\mathrm{p}=0.01)$ (fig 1$)$. There was no significant difference between the level of ET- 1 in synovial fluids from patients with RA and OA (data not shown). 


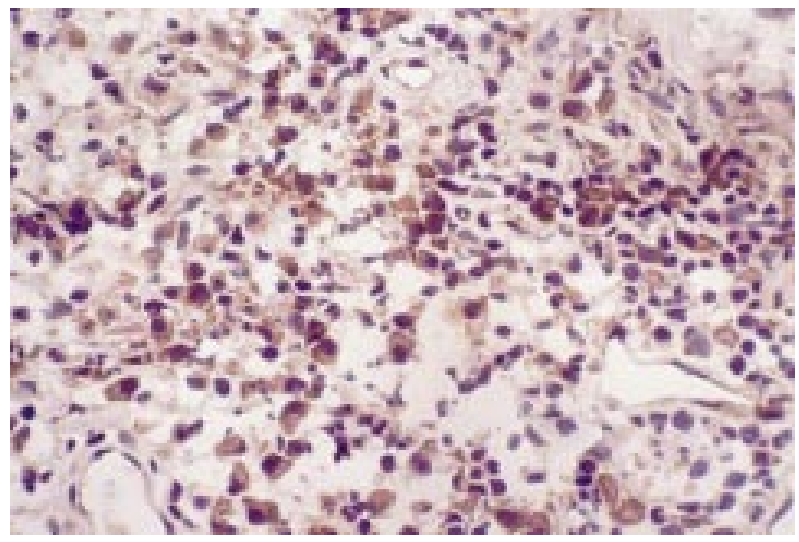

Figure 2 Immunohistochemical staining using anti-AM antibody. AM was positive in endothelial cells in the RA synovium. Original magnification $\times 200$.

AM and ET-1 were positive around the perivascular and endothelial cells in the synovial tissue from patients with RA (fig 2, web extra fig W2). In contrast, the synovial tissue from patients with OA was negative. AM reduced constitutive production of IL6 from RA synoviocytes dose dependently. A high concentration of $\mathrm{AM}\left(\geqslant 10^{-8} \mathrm{mmol} / \mathrm{l}\right)$ significantly reduced constitutive production of IL6 compared with a low concentration of AM $\left(\leqslant 10^{-9} \mathrm{mmol} / \mathrm{l}\right)$ $(\mathrm{p}=0.0029)$. TNF $\alpha$ dose dependently induced production of IL6 from RA synoviocytes (data not shown). AM did not reduce IL6 production induced by TNF $\alpha$ (data not shown).

Our study showed that the concentration of total and mature AM in synovial fluids was significantly higher in patients with RA than in patients with OA. In addition, by immunohistochemical staining, AM and ET-1 were shown to be positive around the perivascular area, the endothelial cells, and synoviocytes in RA synovial tissue. We have reported that osteoclasts are present in synovial tissues from patients with RA and that IL6 and soluble IL6 receptors in synovial fluids may participate in osteoclast formation. ${ }^{8}$ Thus, IL6 is responsible for joint destruction in the presence of soluble IL6 receptor through osteoclastogenesis. In this study we showed that
AM reduced constitutive production of IL6 from RA synoviocytes dose dependently. Thus, our results suggest that AM in patients with RA inhibits both synovitis and osteoclastogenesis through the inhibition of IL6 production.

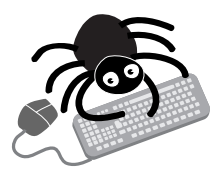

Additional figures can be found on the website at www.annrheumdis.com

\section{Authors' affiliations}

Y Nanke, S Kotake, K Yonemoto, S Saito, T Tomatsu, N Kamatani, Institute of Rheumatology, Tokyo Women's Medical University, 10-22 Kawada-cho, Shinjuku-ku, Tokyo 162-0054, Japan

Correspondence to: Dr Y Nanke; ynn@ior.twmu.ac.jp

Accepted 17 May 2002

\section{REFERENCES}

1 Kitamura K, Kanagaw K, Kawamoto M, Ichiki Y, Nakamura S, Matsuo $\mathrm{H}$, et al. Adrenomedullin: a novel hypotensive peptide isolated from human pheochromocytoma. Biochem Biophys Res Commun $1993: 192: 553-60$

2 Ishiyama Y, Kitamura K, Ichiki Y, Nakamura S, Kida O, Kangawa K, et al. Hemodynamic effects of a novel hypotensive peptide isolated from human adrenomedullin in rats. Eur J Pharmacol 1993;241:271-3.

3 Sugo S, Minamino N, Shoji H, Kangawa K, Kitamura K, Eto T, et al. Interleukin-1, tumor necrosis factor and lipopolysaccharide additively stimulate production of adrenomedullin in vascular smooth muscle cells. Biochem Biophys Res Commun 1995;207:25-32.

4 Kamoi H, Kanazawa H, Hirata K, Kurihara N, Yano Y, Otani S. Adrenomedullin inhibits the secretion of cytokine-induced neutrophil chemoattractant, a member of the interleukin-8 family, from rat alveolar macrophages. Biochem Biophys Res Commun 1995;21 1:1031-5.

5 Nanke Y, Kotake S, Shimamoto K, Hara M, Kamatani N. Raised plasma adrenomedullin in patients with systemic sclerosis complicated by pulmonary hypertension. Ann Rheum Dis 2000;59:493-4.

6 Kotake S, Udagawa N, Takahashi N, Matsuzaki K, Itoh K, Ishiyama S, et al. IL-17 in synovial fluids from patients with rheumatoid arthritis is a potent stimulator of osteoclastogenesis. J Clin Invest 1999; 103:1345-52.

7 Arnett FC, Edworthy SM, Bloch DA, McShane DJ, Fries JF, Cooper NS, et al.The American Rheumatism Association 1987 revised criteria for the classification of rheumatoid arthritis. Arthritis Rheum 1988;31:315-24.

8 Kotake S, Sato K, Kim K, Takahashi N, Udagawa N, Nakamura I, et al. Interleukin-6 and soluble interlekin-6 receptors in the synovial fluids from rheumatoid arthritis patients are responsible for osteoclast-like cell formation. J Bone Miner Res 1996;11:88-9.

\title{
Abnormal $\lg A$ levels in patients with rheumatoid arthritis
}

\author{
L J Badcock, S Clarke, P W Jones, P T Dawes, D L Mattey
}

Ann Rheum Dis 2003;62:83-84

$\mathrm{T}$ he dominant antibody at mucous membranes and in exocrine secretions is IgA. It has been implicated in the pathogenesis of rheumatoid arthritis (RA), possibly due to immune complex formation. ${ }^{12}$ If IgA is important in RA pathogenesis one might predict that patients with abnormal levels would have different characteristics from the "normal" IgA population. Limited work published on patients with high IgA levels has suggested that there is an increase in erythrocyte sedimentation rate (ESR), microscopic haematuria, and both distal interphalangeal joint involvement and unilateral sacroiliitis, even though patients fulfil the American College of Rheumatology (ACR) criteria for RA and have no other evidence of spondyloarthropathy. ${ }^{3}$

Primary selective IgA deficiency is the most common hypogammaglobulinaemia in the general population, with a prevalence of around 1:500. ${ }^{4}$ It is associated with increased risk of autoimmune disease ${ }^{5}$ and, possibly, with RA. ${ }^{6}$ Primary IgA deficiency may result from impaired switching from class IgM to IgA. ${ }^{7}$ Secondary IgA deficiency may be caused by drugs such as D-penicillamine, sulfasalazine, and gold. The few descriptions of primary IgA deficiency and RA have been single case studies and a longitudinal study is needed to determine if these cases represent a subgroup.

\section{METHODS AND RESULTS}

Serum immunoglobulins were measured in 352 patients (aged 18-75) attending a rheumatology outpatient department over a six year period. All patients fulfilled the ACR criteria for diagnosis of RA. ${ }^{8}$ Patients with selective hypergammaglobulinaemia $(>240 \mathrm{IU} / \mathrm{ml})$ or primary selective IgA deficiency $(<50 \mathrm{IU} / \mathrm{ml})$ were identified as the two study cohorts. These 
Table 1 Comparison of clinical features in patients with RA with normal and abnormal lgA levels. Value of the clinical feature (95\% confidence interval) shown where a range is given

\begin{tabular}{|c|c|c|c|}
\hline Variable & High IgA group $(n=22)$ & Low IgA group $(n=8)$ & RA controls $(n=277)$ \\
\hline Male:female & $7: 15$ & $2: 6$ & $88: 189$ \\
\hline Mean age at assessment & 56.0 (52 to 60$)$ & 56.8 (43 to 71$)$ & 52.1 (48 to 57$)$ \\
\hline Mean age of onset & 50.0 (45 to 55$)$ & 49.8 (37 to 62$)$ & 46.3 (45 to 49 ) \\
\hline No with 1 st degree relative with RA & $11(20)$ & $5(7)^{*}$ & $99(277)$ \\
\hline Median Steinbrocker score & $2.3(1.9$ to 2.6$)$ & $2.0(1.4$ to 2.6$)$ & 2.1 (2.0 to 2.2$)$ \\
\hline Mean tender joint count & $8.9(6.6$ to 11.3$)$ & $10.0(5.0$ to 15.0$)$ & 9.0 (7.7 to 10.3$)$ \\
\hline No with nodules & $3(20)$ & $0(7)$ & $53(275)$ \\
\hline Mean CRP & 49.7 (32.0 to 67.3$)$ & 62.9 (31.7 to 94.0 ) & 45.2 (39.7 to 50.7 ) \\
\hline No with positive RA latex (>1/40) & $11(20)$ & $6(7)$ & $168(275)$ \\
\hline No with positive ANF (>1/40) & $5(20)$ & $2(7)$ & $54(275)$ \\
\hline Mean ESR over 18 months & 40.6 (32.1 to 49.0$)$ & 33.0 (20.4 to 45.6$)$ & 29.9 (26.2 to 32.9 ) \\
\hline Mean CRP over 18 months & $40.8(28.4$ to 53.1$)$ & $31.5(15.0$ to 48.0$)$ & $29.1 \quad(26.4$ to 32.7$)$ \\
\hline Mean tender joint count over 18 months & $7.6(6.1$ to 9.2$)$ & $7.3(2.9$ to 11.7$)$ & $7.2(6.0$ to 8.4$)$ \\
\hline \multicolumn{4}{|l|}{ Long term follow up } \\
\hline Mean HAQ score & $1.7(1.1$ to 2.2$)(15)$ & & $1.5(1.4$ to 1.6$)$ \\
\hline No with one or more large joints replaced & $8(21)$ & $3(8)$ & $87(276)$ \\
\hline Mean no of large joints replaced per patient & $0.8(0.2$ to 1.3$)$ & $0.75(0.2$ to 1.7$)$ & $0.9(0.7$ to 1.1$)$ \\
\hline No died over 15 years & 8 & 2 & 61 \\
\hline
\end{tabular}

were compared with patients with RA $(n=277)$ with normal IgA levels. No patients had been treated with immunosuppressant drugs at the time of IgA determination. Measurements of disease activity and disability were made at $0,6,12$, and 18 months. A long term follow up assessment (including Health Assessment Questionnaire 9 and joint surgery) was made at about 12 years. Mortality was assessed after 15 years.

Of 352 patients, eight had a primary selective IgA deficiency, a point prevalence of $2.3 \%$. A further three had a low IgA as part of combined immunoglobulin deficiency. Twenty two patients had a selective IgA hypergammaglobulinaemia, a point prevalence of $6.3 \%$, with a further 28 having a high IgA combined with abnormal levels of IgG or IgM. The IgA deficient patients were more likely to have a first degree relative with RA than the overall RA population and none of this group had RA nodules compared with $29 \%$ of RA controls (table 1). There was a tendency for the high IgA group to have a higher ESR and $\mathrm{C}$ reactive protein over the first 18 months than the low IgA group and controls. The long term outcome data demonstrated no significant difference in joint damage, joint replacement surgery, or mortality.

\section{DISCUSSION}

As far as we know, this study is the first to examine long term outcome in patients with RA with abnormal IgA levels, and to investigate the prevalence of IgA deficiency. The latter has been associated with other autoimmune diseases, suggesting that it may predispose a person to autoimmune dysfunction. Although most cases of primary IgA deficiency are spontaneous, familial cases have been described. In our study, IgA deficient patients were more likely to have a history of RA in first degree relatives, suggesting inheritance of a predisposing factor. Though numbers were small, no similar published study was found. The lack of power caused by small sample sizes might have prevented us demonstrating more significant differences. None the less, the findings are of interest. As in previous work the high IgA group possibly had more active disease. However, there was little overall difference between the patients with abnormal IgA levels and the controls. These findings do not support a role for IgA as a key factor in the pathogenesis of RA, or its clinical presentation.

\section{Authors' affiliations}

L J Badcock, Derbyshire Royal Infirmary, Derby, UK

S Clarke, P T Dawes, D L Mattey, Staffordshire Rheumatology Centre,

Haywood Hospital, Stoke-on-Trent, UK

P W Jones, Department of Mathematics, Keele University, UK

Correspondence to: Dr D L Mattey, Staffordshire Rheumatology Centre, Haywood Hospital, Stoke-on-Trent, Staffordshire ST6 7AG, UK: dlmattey@netscape.net

Accepted 17 May 2002

\section{REFERENCES}

1 Westedt ML, Daha MR, Baldwin WM, Stijnen T, Cats A. Serum immune complexes containing $\lg A$ appear to predict erosive arthritis in a longitudinal study in rheumatoid arthritis. Ann Rheum Dis 1986:45:809-15.

2 Davis MJ, Dawes PT, Fowler PD, Shadforth MF, Lewin I, Stanworth DR. The association and predictive value of the complex immunoglubulin A$\alpha 1$ antitrypsin in the development of erosions in early rheumatoid arthritis. Scand J Rheumatol 1991;20:23-7.

3 Sfriso P, Lazzarin P, Punzi L, Ostuni PA, lanniello A, Gamari PF. Clinical, radiological and laboratory aspects of rheumatoid arthritis associated with high serum levels of IgA. Clin Exp Rheumatol 1994;12:690-1.

4 Holt PDJ, Tandy NP, Antsee DJ. Screening of blood donors for $\lg A$ deficiency: a study of the donor population of south-west England. J Clin Pathol 1977;30:1007-10.

5 Goshen E, Livne A, Krupp M, Hammarstrom L, Dighiero G, Slor H, et al. Antinuclear and related autoantibodies in sera of healthy subjects with IgA deficiency. J Autoimmun 1989;2:51-60.

6 Koskinen S. Long-term follow-up of health in blood donors with primary selective lgA deficiency. J Clin Immunol 1996;16:165-70.

7 Islam KB, Baskin B, Nilsson L, Hammarstrom L, Sideras P, Smith Cl. Molecular analysis of $\lg A$ deficieny. Evidence for impaired switching to IgA. J Immunol 1994;152:1442-52.

8 Arnett FC, Edworthy SM, Bloch DA, McShane DJ, Fries JF, Cooper NS, et al. The American Rheumatism Association 1987 revised criteria for the classification of rheumatoid arthritis. Arthritis Rheum 1988;31:315-24.

9 Kirwan JR, Reeback JS. Stanford Health Assessment Questionnaire modified to assess disability in British patients with rheumatoid arthritis. Br J Rheumatol 1986;25:206-9. 


\title{
Asymptomatic diffuse pulmonary embolism caused by acrylic cement: an unusual complication of percutaneous vertebroplasty
}

\author{
J Bernhard, P F Heini, P M Villiger
}

Ann Rheum Dis 2003;62:85-86

$\mathrm{P}$ rcutaneous vertebroplasty was first performed in 1984. Galibert et al treated a cervical vertebral angioma by percutaneous puncture and injection of polymethylmethacrylate (PMMA) cement into the vertebral body. ${ }^{1}$ Shortly thereafter vertebroplasty was done also in lytic metastatic bone lesions. ${ }^{2}$ Vertebroplasty for the treatment of vertebral fractures in osteoporosis has gained fast acceptance in the past two years. Its efficacy is documented in several clinical studies. ${ }^{34}$
However, open questions about indication, technical aspects, and complications remain. We report the first case of extensive but clinically silent cement embolisation into the lungs.

\section{CASE REPORT}

A 67 year old man presented with upper abdominal pain. A chest radiograph suggested multiple vertebral fractures as a possible explanation. Magnetic resonance imaging confirmed
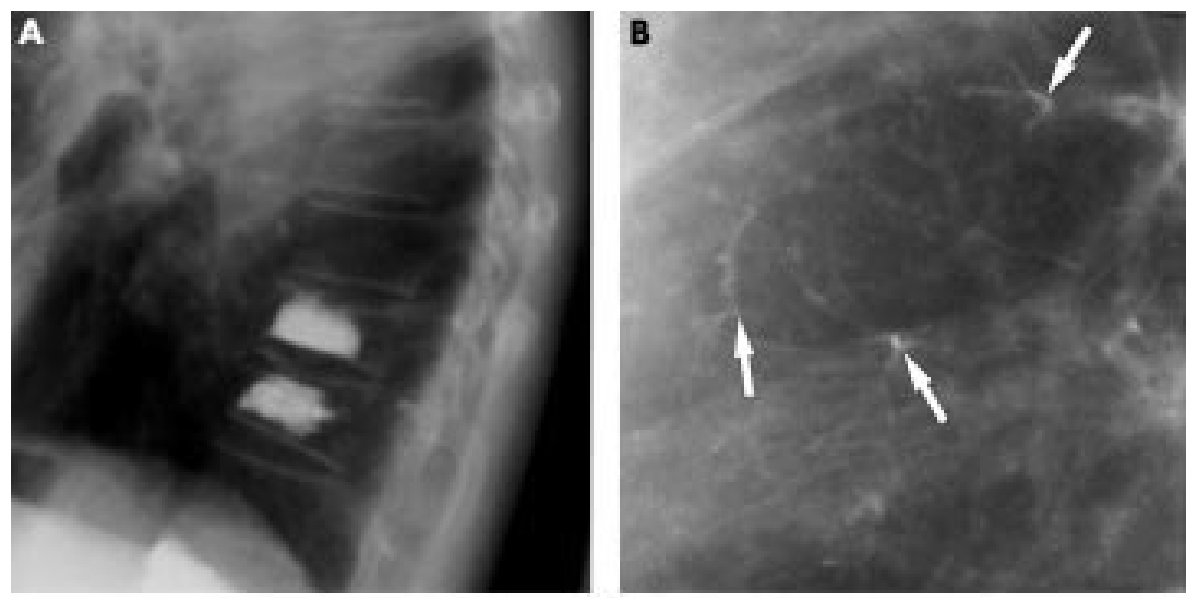

Figure 1 (A) Six months after vertebroplasties the chest radiographs show radiodense cement in the

fractured vertebral bodies T10, TI 1 , and L1. (C and D) Posteroanterior views of the right lung. The pulmonary arterial vessels look normal before the vertebroplasties (C). In contrast multiple radiodense lines along the pulmonary vessels are detectable thereatter. (B) Shows a more detailed view of (D). Three of the cement emboli are marked with white arrows.
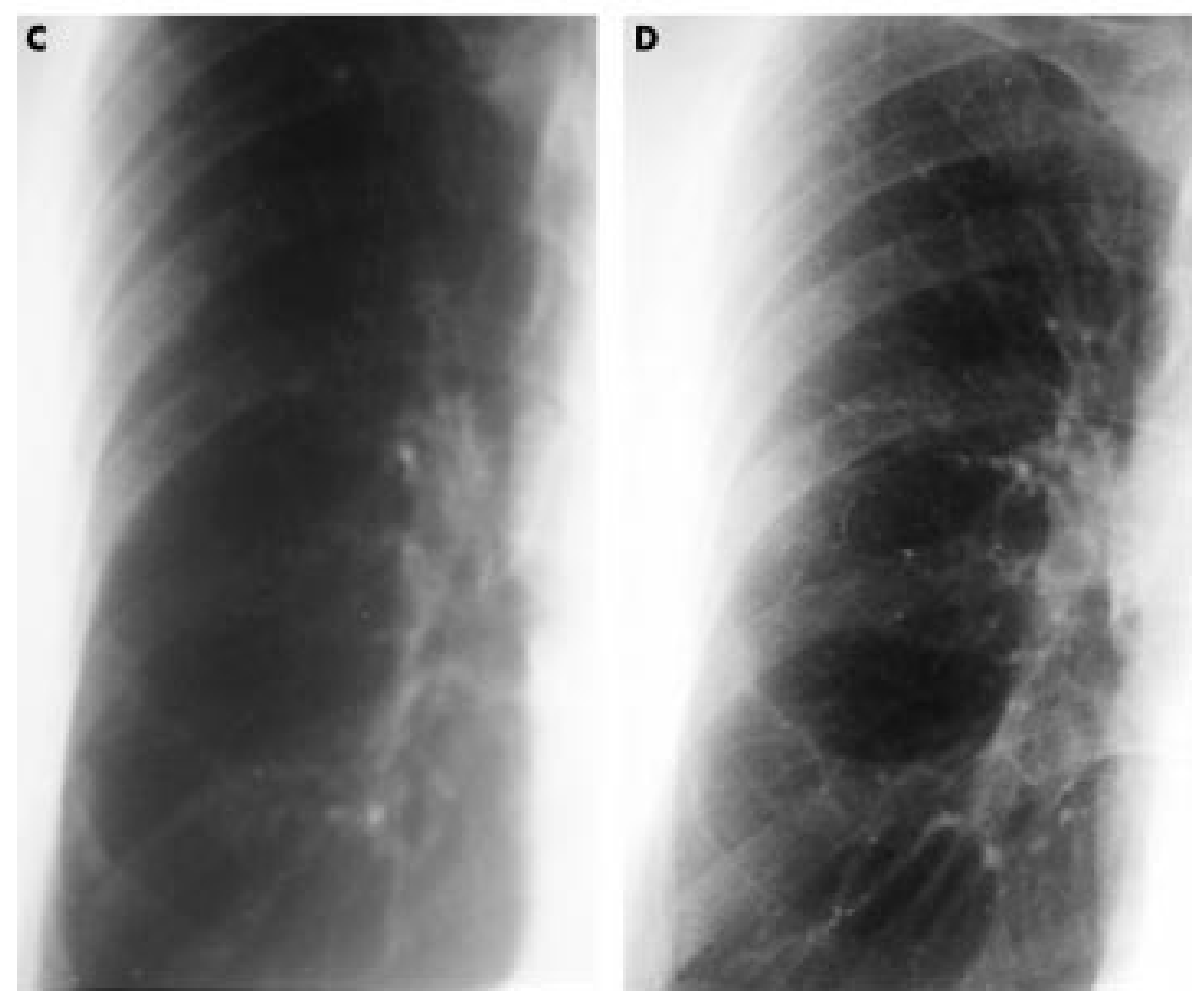
fresh osteoporotic fractures. The patient was admitted in April 2000 for percutaneous vertebroplasties. After local anaesthesia, the needle was placed transpedicularly into the vertebral bodies. Under fluoroscopic control the cement was injected without any complication in the vertebral bodies T10 and T11 (fig 1A). As the needle was pulled out of the vertebral body Ll, the patient felt an intense pain in the left thigh. A computed tomographic (CT) scan performed within a few hours depicted a haematoma in the left psoas muscle. The patient did not feel any respiratory or thoracic discomfort and was discharged a few days later.

Because of persisting pain in the lower back the patient was referred to our clinic six months later. His history disclosed heavy smoking and a weight loss of $7 \mathrm{~kg}$ during the past five months. He denied any respiratory symptoms. Clinical examination showed a body weight of $46 \mathrm{~kg}$ and a height of $1.64 \mathrm{~m}$. Cardiac and respiratory findings were normal. The gait was ataxic, with absent Achilles tendon reflexes and marked muscle wasting. The chest radiograph did not show any signs of a neoplastic disease, but a large number of fine radiodense lines with a branching pattern spreading throughout both lungs was seen (figs $1 \mathrm{~B}$ and D).

\section{DISCUSSION}

Percutaneous vertebroplasty is a minimally invasive technique mainly for the treatment of vertebral fractures in osteoporosis and fractures due to spinal metastasis. ${ }^{3-5}$ In up to $90 \%$ of cases, immediate pain relief is reported. The risk of cement extravasation into the venous system and the spinal canal represents the major hazard of this technique. The leakage of acrylic cement outside the vertebral body occurs in up to $65 \%$ but remains silent in most cases. The extravasation of cement into the inferior vena cava and subsequently into the lungs is rare. To date, only three cases of patients with pulmonary embolism caused by percutaneous vertebroplasty have been reported. ${ }^{36}$ All the cases showed paravertebral venous opacity, the embolisation was documented by CT scan and two of the patients remained asymptomatic. ${ }^{3}$ In addition, one case of lethal pulmonary embolism was reported after percutaneous vertebroplasty in a series of patients with spinal metastasis. It is important to note, however, that no cement was found in the pulmonary arteries. ${ }^{7}$

The risk of cement leakage depends on the vascular anatomy and fracture pattern, on the one hand, and technical aspects, on the other. The case presented here shows a typical fracture pattern without involvement of the posterior wall and offers no additional risks for this treatment. The viscosity of PMMA cement is a crucial aspect during the procedure. The occurrence of this diffuse, extensive lung embolisation is only possible when a considerable amount of cement is injected in a very low viscous state. The cases mentioned above showed only globular cement in major pulmonary vessels. Furthermore, sufficient radio-opacity of the cement is mandatory. In addition, the placement of the tip of the needle needs to be controlled by CT scan or fluoroscopy. As the performing radiologist did not detect dislocation of cement, we suspect a lesion of the basivertebral vein or a horizontal subarticular collecting vein draining into the vena cava inferior at the Ll level in our case. The value of prior vertebrography is controversial. Some authors recommend a venography to exclude needle placement directly within the basivertebral venous plexus. Others argue that the contrast media has different chemical and physical properties and nearly always escapes through the venous plexus. Our experience suggests that extravasation cannot be avoided by previous venography and, therefore, meticulous monitoring of the cement flow during the procedure is crucial.

This case illustrates for the first time diffuse pulmonary cement emboli as a complication of percutaneous vertebroplasty. It supports the notion that plugging a small percentage of arterial pulmonary vessels does not result in respiratory symptoms. However, whether the stiffness or the chemical properties of the cement, or both, may lead to secondary pulmonary lesions is unknown.

\section{Authors' affiliations \\ J Bernhard, P M Villiger, Department of Rheumatology and Clinical Immunology/Allergology, University Hospital, CH-3010 Berne, Switzerland \\ P F Heini, Department of Orthopaedic Surgery, Spine Service, University Hospital , CH-3010 Berne, Switzerland}

Correspondence to: Professor P M Villiger; Peter.Villiger@Insel.ch

Accepted 27 May 2002

\section{REFERENCES}

1 Galibert P, Deramond H, Rosat P, Le Gars D. Note préliminaire sur le traitment des angiomes vertébraux par vertébroplastie acrylique percutanée. Neurochirurgie 1987:33:166-8.

2 Kaemmerlen $P$, Thiesse $P$, Bouvard $H$, Biron $P$, Mornex F, Jonas $P$. Vertébroplastie percutanée dans le traitment des métastases. Téchnique et résultats. J Radiol 1989;70:557-62.

3 Gangi A, Dietemann JL, Guth S, Steib JP, Roy C. Computed tomography (CT) and fluoroscopy guided vertebroplasty: results and complications in 187 patients. Sem Intervent Radiol 1999-16:137-142.

4 Heini PF, Wälchli B, Berlemann U. Percutaneous transpedicular vertebroplasty with PMMA: operative technique and early results. Eur Spine J 2000;9:445-50

5 Cotten A, Dewatre F, Cortet B, Assaker R, Leblond D, Duquesnoy B, et al. Percutaneous vertebroplasty for osteolytic metastases and melanoma: effects of the percentage of lesion filling and the leakage of methyl methacrylate at clinical follow-up. Radiology 1996;200:525-30.

6 Padovani B, Kasriel O, Brunner Ph, Peretti-Viton P. Pulmonary embolism caused by acrylic cement: a rare complication of percutaneous vertebroplasty. AJNR Am J Neuroradiol 1999;20:375-7.

7 Weill A, Chiras J, Simon JM, Rose M, Sola-Martinez T, Enkaoua E. Spinal metastases: indications for and results of percutaneous injection of acrylic surgical cement. Radiology 1996;199:241-7.

\section{No association between human parvovirus B19 infection and Siögren's syndrome}

\section{R De Stefano, S Manganelli, E Frati, E Selvi, A Azzi, K Zakrzewska, R Marcolongo}

$\mathrm{T}$ he association of human parvovirus B19 (HPVB19) infection with autoimmune disease, including systemic lupus erythematosus, rheumatoid arthritis, polymyositis, and vasculitis, has been suggested, although the exact relationship between the infection and these disorders has not been fully elucidated. ${ }^{12}$ A recent report showed serologi- cal evidence of past B19 infection associated with the presence of cytopenia in patients with primary Sjögren's syndrome (SS). ${ }^{3}$ To gain more information about the aetiopathogenetic role of HPVB19 for this disease, we evaluated the presence of the viral genome in minor salivary glands from patients with primary SS. 
We studied 10 women with SS (mean (SD) age 45 (9) years) and 10 healthy controls matched for age (43 (6) years) and sex. SS was diagnosed according to European criteria. ${ }^{4}$ Each subject taking part in the study underwent minor salivary gland $6 \mathrm{~mm}$ punch biopsy under local anaesthesia. Histological evaluation of biopsy samples was carried out according to Chisholm and Mason's classification. ${ }^{5}$ They were also analysed for the presence of DNA sequence coding for the HPVB19 non-structural protein (NSl) amplified by nested polymerase chain reaction (PCR) as a marker of infection. The outer primer pairs were $\mathrm{Pl}$ and $\mathrm{P} 6$, corresponding to nucleotides 1399-1422 and 1682-1659. In the second amplification, the P2 and P5 inner nested primer pairs, corresponding to nucleotides 1498-1525 and 1660-1576, were used. The 103 base pair (bp) diagnostic fragment was subsequently detected by ethidium bromide staining after agarose gel electrophoresis. Each sample was tested in duplicate. A $10^{-9}$ dilution of a reference serum containing about 10-100 HPVB19 genome copies was used as positive control. Negative water controls were extracted concomitantly with the diagnostic specimens in order to monitor possible contamination during the extraction step. Additional negative controls were included in each PCR run to eliminate the possibility of carryover contamination. A $268 \mathrm{bp}$ fragment of the $\beta$-globin gene was amplified using primers PC04 and GH20 as a test for the absence of Taq DNA polymerase inhibitors and to estimate the quantity of DNA extracted from each minor salivary gland. A serial 10-fold dilution of DNA extracted from a known number of Hep-2 cells was used as positive control. Negative controls were simultaneously extracted water samples. PCR products were then analysed by agarose gel electrophoresis.

Blood samples from each patient were tested for the presence of anti-B19 IgM and IgG using a commercially available enzyme linked immunosorbent assay (ELISA) (Pantec, Torino-Italy).

All minor salivary gland samples of patients with SS were rated as grade III or IV according to Chisholm-Mason's classification. In the control group, only three subjects were rated as grade I or II (subjects 13, 14, and 17, table 1).

The DNA sequence coding for NSI of HPVB 19 was found in a salivary gland specimen from one case of SS (patient 2) and from one control subject (subject 19). Both cases showed a high titre of anti-B19 IgG antibodies and the absence of specific IgM antibodies. In the patient with SS (patient 2) the presence of IgG B19 antibodies was associated with more than one focus score, whereas in the control subject (subject 19) the presence of DNAPVB19 was not associated with lymphocytic infiltrate. Anti-B19 IgG antibodies, but no anti-B19 IgM antibodies, were detected in three other subjects, including one with SS (patient 6) and two controls (subjects 12 and 17). The results of the study showed that the prevalence of past B19 infection in patients with primary SS was similar to that of the control group. Furthermore, none of the patients with SS showed serological markers of recent infection from HPVB19.
Table 1 Histological and serological features in patients with primary SS and controls. 1-10 are patients, 11-20 controls

\begin{tabular}{cllll}
\hline Subjects & Lymphocytic & & & \\
infiltrate (grade) & IgG & IgM & DNAPVB19 \\
\hline Patients & & & & \\
1 & IV & - & - & - \\
2 & III & + & - & + \\
3 & IV & - & - & - \\
4 & III & - & - & - \\
5 & III & - & - & - \\
6 & IV & + & - & - \\
7 & III & - & - & - \\
8 & IV & - & - & - \\
9 & IV & - & - & - \\
10 & IV & - & - & - \\
Controls & & & & \\
11 & Absent & - & - & - \\
12 & Absent & + & - & - \\
13 & II & - & - & - \\
14 & I & - & - & - \\
15 & Absent & - & - & - \\
16 & Absent & - & - & - \\
17 & I & + & - & - \\
18 & Absent & - & - & - \\
19 & Absent & + & - & + \\
20 & Absent & - & - & - \\
\hline & & & & \\
\hline & & & & \\
\hline & & & & \\
\hline
\end{tabular}

B19DNA can also be found, and can persist, in the salivary glands without inevitably inducing a lymphocytic infiltrate in this tissue. Our results suggest that B 19 constituents may also be found in salivary gland tissue. However, the presence of viral DNA in the salivary glands of patients with SS appears to be incidental, and it does not support an association between SS and HPVB19 infection.

\section{Authors' affiliations}

R De Stefano, S Manganelli, E Frati, E Selvi, R Marcolongo, Institute

of Rheumatology, University of Siena, Italy

A Azzi, K Zakrzewska, Department of Microbiology, University of

Florence, Italy

Correspondence to: Dr S Manganelli, Institute of Rheumatology

University of Siena, 53100 Siena, Italy; s.manganelli@katamail.com

Accepted 7 June 2002

\section{REFERENCES}

1 Trapani S, Ermini M, Falcini F. Human parvovirus B19 infection: its relationship with systemic lupus erythematosus. Semin Arthritis Rheum 1999:28:319-25

2 Kerr J R. Pathogenesis of human parvovirus B 19 in rheumatic disease. Ann Rheum Dis 2000;59:672-83.

3 Ramon-Casals M, Cervera R, Garcia-Carrasco M, Vidal J, Trejo O, Jimenez $S$, et al. Cytopenia and past human parvovirus B 19 infection in patient with primary Siögren's syndrome. Semin Arthritis Rheum 2000;29:373-8

4 Vitali C, Bombardieri S, Moutsopoulos HM, Balestrieri G, Bencivelli W, Bernstein RM, et al. Preliminary criteria for the classification of Siögren's syndrome. Arthritis Rheum 1993;36:340-7.

5 Chisholm DM, Mason DK. Labial salivary gland biopsy in Sjögren's syndrome. J Clin Pathol 1968;21:656-60. 


\title{
Recurrent uveitis in a patient with juvenile spondyloarthropathy associated with tumour necrosis factor $\alpha$ inhibitors
}

\author{
O Kaipiainen-Seppänen, $M$ Leino
}

Ann Rheum Dis 2003;62:88-89

$\mathrm{T}$ umour necrosis factor $\alpha(\mathrm{TNF} \alpha)$ antagonists have been shown to be effective in controlling symptoms in patients with rheumatoid arthritis (RA) ${ }^{12}$ and juvenile RA (JRA). ${ }^{1}$ The most common adverse events associated with etanercept are injection site reactions and infections, and with infliximab, headache, infections and, occasionally, infusion related reactions. ${ }^{2}$ Cutaneous vasculitis associated with etanercept has been described in three patients, and one of them also had a similar skin manifestation secondary to the treatment with infliximab. ${ }^{3}$ The possible association of a demyelinating syndrome with the use of anti-TNF agents in inflammatory arthritides needs further surveillance.

\section{CASE REPORT}

A 31 year old female patient has had juvenile rheumatic disease since the age of 10 . She has had a polyarticular disease in her peripheral joints with inflammatory manifestations both in the cervical spine and sacroiliac joints. She is HLA-B27 positive. At the time of diagnosis she was treated with aurothiomalate and hydroxychloroquine, but they were withdrawn because of side effects. During treatment with D-penicillamine remission was achieved. This drug was discontinued after treatment of 2.5 years. Between 1984 and 1989 she was in remission. Thereafter she was treated with D-penicillamine, azathioprine, podophyllotoxin, auranofin, chlorambucil, cyclosporin, and methotrexate, either each drug alone or in the 1990s with a combination of two drugs. Most often the combinations included methotrexate, which she has used continuously since May 1995. Many of the aforementioned drugs were withdrawn because of side effects, but some of them owing to lack of efficacy. Her joint disease was continuously active.

In July 1999, etanercept $25 \mathrm{mg}$ twice weekly was started and methotrexate was continued with a small dose reduction from $25 \mathrm{mg}$ to $20 \mathrm{mg} /$ week. Her joint disease responded well to this combination treatment; within three months she gained remission. Her haemoglobin rose from 91 to $124 \mathrm{~g} / \mathrm{l}$, the erythrocyte sedimentation rate (ESR) decreased from 60 to $8 \mathrm{~mm} / \mathrm{lst} \mathrm{h}$, and C reactive protein (CRP) from 44 to $5 \mathrm{mg} / \mathrm{l}$. In March 2000, for the first time during her longlasting disease, she had acute anterior uveitis, which ran a chronic course. From June to August 2000 the dose of etanercept was reduced to $25 \mathrm{mg} /$ week and it was discontinued at the end of August 2000. Inflammation in her eye was temporarily depressed, but it was reactivated again in December 2000 and March 2001. Between September 2000 and May 2001 she was treated with a combination of prednisolone, methotrexate, and leflunomide, but the joint disease flared. Leflunomide was discontinued and infliximab infusions were started in May 2001. Corticosteroid treatment was withdrawn after the first infusion. Uveitis in her right eye relapsed in March 2002, but it responded to topical corticosteroids in two weeks. At that time her joint disease was in remission, the ESR was $7 \mathrm{~mm} / \mathrm{lst} \mathrm{h}$ and CRP $<5 \mathrm{mg} / \mathrm{l}$.

\section{DISCUSSION}

Chronic uveitis is an important complication of JRA. Uveitis is usually asymptomatic and often bilateral. It becomes manifest usually within seven years from the onset of arthritis. ${ }^{5}$ In epidemiological studies the incidence of uveitis has varied from 4 to $16 \%$ among patients with JRA in population based series. ${ }^{67} \mathrm{Up}$ to $27 \%$ of patients with juvenile onset ankylosing spondylitis have one or more attacks of non-granulomatous acute uveitis. ${ }^{8}$

Among 16 patients who had inflammatory eye disease (uveitis or scleritis), 13/16 also having an associated joint disease, and who were treated with etanercept or infliximab, the joint disease responded excellently to treatment, but the eye disease improved in only 6/16 patients (38\%). ${ }^{9}$ Five patients developed an inflammatory eye disease for the first time while taking a TNF inhibitor. Among 10 children with uveitis refractory to long term treatment, 3/14 (21\%) eyes achieved remission, 5/14 (36\%) eyes improved, 5/14 eyes (36\%) remained unchanged, and one eye $(7 \%)$ worsened during etanercept treatment. ${ }^{10}$ In endotoxin induced uveitis in mice, both pretreatment with TNF $\alpha$ or with anti-TNF $\alpha$ antibody caused the ocular inflammation to worsen significantly. ${ }^{11}$ Thus, TNF $\alpha$ blockade may also stimulate certain aspects of immune defence, exacerbating immune reaction in the tissues which TNF inhibitors do not effectively penetrate, such as the central nervous system, ${ }^{4}$ or the eye. The peripheral joint disease responded well to both TNF inhibitors in our patient. Although a disease associated manifestation cannot be excluded, recurrences of uveitis, when the joint disease was in remission, may be secondary to TNF inhibition. Both etanercept and infliximab induced similar cutaneous vasculitis in a susceptible patient, which might be due to anti-drug antibody production or perturbation in the TNF/TNF receptor system in the target organ. ${ }^{3}$ It was recently shown that peripheral T cell reactivity was increased after four and eight weeks of etanercept treatment among patients with RA. ${ }^{12}$ Surveillance of large patient groups is needed to reveal the magnitude of immune reactions associated with TNF $\alpha$ blockade.

\section{Authors' affiliations}

O Kaipiainen-Seppänen, Department of Medicine, Kuopio University Hospital, Kuopio, Finland

M Leino, Department of Ophthalmology, Kuopio University Hospital, Kuopio, Finland

Correspondence to: $\operatorname{Dr} O$ Kaipiainen-Seppänen, Department of Medicine, Kuopio University Hospital, PO Box 1777, 70211 Kuopio, Finland; Oili.Kaipiainen-Seppanen@kuh.fi

Accepted 17 May 2002

\section{REFERENCES}

1 Garrison L, McDonnell ND. Etanercept: therapeutic use in patients with rheumatoid arthritis. Ann Rheum Dis 1999;58:(suppl I):i 165-9.

2 Maini R, St Clair EW, Furst D, Kalden J, Weisman M, Smolen J, et al. Infliximab (chimeric anti-tumor necrosis factor $\alpha$ monoclonal antibody) versus placebo in rheumatoid arthritis patients receiving concomitant methotrexate: a randomised phase III trial. Lancet 1999;354:1932-9.

3 McCain ME, Quinet R, Davis WE. Entanercept and infliximab associated with cutaneous vasculitis. Rheumatology (Oxford) 2002;41:1 16-17.

4 Mohan N, Edwards ET, Cupps TR, Oliverio PJ, Sandberg G, Crayton H, et al. Demyelination occurring during anti-tumor necrosis factor $\alpha$ therapy for inflammatory arthritides. Arthritis Rheum 2001;44:2862-9.

5 Kanski JJ. Juvenile arthritis and uveitis. Surv Ophthalmol 1990;34:253-67. 
6 Towner SR, Michet CJ Jr, O'Fallon WM, Nelson AM. The epidemiology of juvenile arthritis in Rochester, Minnesota 1960-1979. Arthritis Rheum 1983;26:1208-13

7 Kotaniemi K, Kaipiainen-Seppänen O, Savolainen A, Karma A. A population-based study on uveitis in juvenile rheumatoid arthritis. Clin Exp Rheumatol 1999.17:119-22.

8 Burgos-Vargas R, Pacheco-Tena C, Vázquez-Mellado J. Juvenile-onset spondyloarthropathies. Rheum Dis Clin North Am 1997;23:569-98.

9 Reiff A, Takei S, Sadeghi S, Stout A, Shaham B, Bernstein B, et al.

Etanercept therapy in children with treatment-resistant uveitis. Arthritis

Rheum 2001:44:1411-15.
10 Smith RJ, Levinson RD, Holland GN, Jabs DA, Robinson MR, Whitcup $S M$, et al. Differential efficacy of tumor necrosis factor inhibition in the management of inflammatory eye disease and associated rheumatic disease. Arthritis Care Res 2001;45:252-7.

11 Kasner L, Chan CC, Whitcup SM, Gery I. The paradoxical effect of tumor necrosis factor alpha (TNF- $\alpha$ ) in endotoxin-induced uveitis. Invest Ophthalmol Vis Sci 1993;34:2911-17.

12 Berg L, Lampa J, Rogberg S, van Vollenhoven R, Klareskog L. Increased peripheral T cell reactivity to microbial antigens and collagen type II in rheumatoid arthritis after treatment with soluble TNF $\alpha$ receptors. Ann Rheum Dis 2001;60:133-9.

\title{
Enhancement by iron of interleukin 1 induced granulocyte macrophage colony stimulating factor (GM-CSF) production by human synovial fibroblasts
}

\author{
K Nishiya, H Wang, K Tahara, K Hashimoto
}

Ann Rheum Dis 2003;62:89-90

ron infusion activates synovium and induced joint inflammation in experimental animals and causes the flaring up of arthritis in patients with rheumatoid arthritis (RA). Marked iron deposition in RA synovia has been reported over the past 30 years and has also recently been demonstrated by quantitative photometric assessment and is correlated with exudative and proliferative histological features. ${ }^{1}$ It has been reported that the amount of iron deposition in RA synovial tissue is correlated with disease activity and severity. Iron has an important role in RA synovitis through the formation of radical oxygen species, and the enhancement of collagen synthesis and synovial fibroblast proliferation ${ }^{2}$ possibly owing to down regulation of prostaglandin $\mathrm{E}_{2}\left(\mathrm{PGE}_{2}\right)$ production. ${ }^{3}$

Synovial fibroblasts produce a number of inflammatory mediators including cytokines such as interleukin (IL) l, IL6, IL8, fibroblast growth factor, vascular endothelial growth factor, tumour necrosis factor, and granulocyte macrophage colony stimulating factor (GM-CSF). GM-CSF produces the progenitor cells of macrophage lineage stem cells and stimulates mature granulocytes and macrophages. GM-CSF is produced by T cells, macrophages, and fibroblasts and has been found in synovial fluid and tissue from patients with RA. GM-CSF has an important role in type II collagen induced arthritis in rats and in the acute methylated bovine serum albumin induced murine arthritis model. A protective effect against collagen induced arthritis was seen in GM-CSF knockout mice. Using those mice, it has been recently shown that GM-CSF plays a part in the ILI induced arthritis that follows methylated bovine serum albumin injection. ${ }^{4}$ In this study we showed that iron enhanced GM-CSF but did not enhance IL6 or IL8 production by human synovial fibroblasts on stimulation with IL1 $\beta$ in vitro.

Synovial tissues were obtained from 20 patients, 11 with RA and nine with osteoarthritis. The synovial fibroblasts were isolated according to a method described previously. ${ }^{2}$ The material containing the synovial fibroblasts during the third to seventh passage was used in the experiments. Synovial fibroblasts were added at a concentration of $1 \times 10^{4}$ cells/well to each well of a 96 well microtitre plate, and cultured for $18,24,48,72,96$, and 120 hours with or without recombinant human IL1 $\beta$. The cytokines in the culture supernatant were measured with a commercially available enzyme linked immunosorbent assay (ELISA) kit (Amersham Life Science, UK). Ferric citrate was used as an iron salt or sodium citrate as a control. The differences in cytokine production by synovial fibroblasts cultured with ferric citrate compared with sodium citrate or medium alone were analysed by paired Student's $t$ test. A level of $\mathrm{p}<0.05$ was accepted as significant.

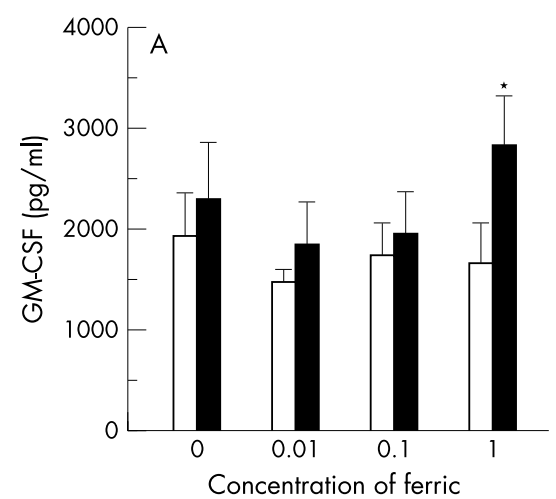

(closed columns) or sodium citrate (open columns) (mmol/I)

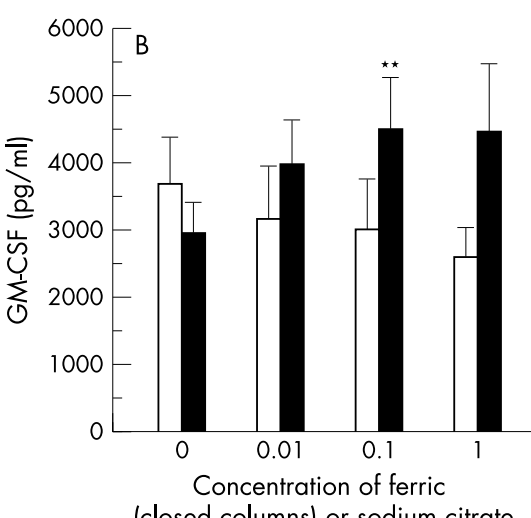

(closed columns) or sodium citrate (open columns) (mmol/l)

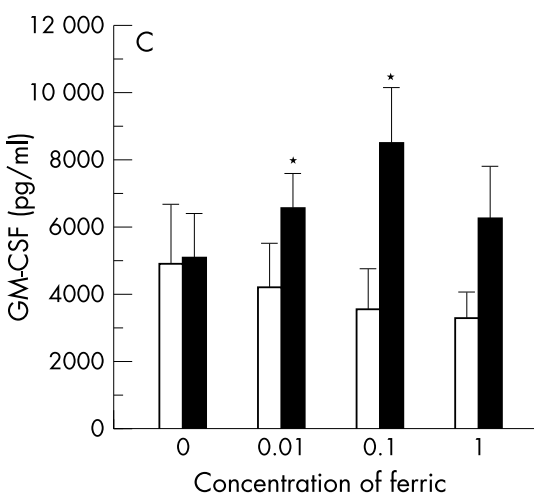

(closed columns) or sodium citrate (open columns) (mmol//)

Figure 1 Effects of iron on ILI $\beta$ induced GM-CSF production by human synovial fibroblasts cultured for 96 hours. Human synovial fibroblasts were stimulated with IL $1 \beta$ in the presence of different concentrations of ferric or sodium citrate. (A) IL $1 \beta 1 \mathrm{ng} / \mathrm{ml}$. (Bars represent means (SEM) of six experiments. ${ }^{*} p<0.05 v$ medium alone). (B) IL $1 \beta 10 \mathrm{ng} / \mathrm{ml}$. ( ${ }^{*} p<0.01 v$ medium alone; $\left.\mathrm{n}=6\right)$. (C) IL $1 \beta 100 \mathrm{ng} / \mathrm{ml}$. ( ${ }^{*} p<0.05 v$ medium alone; $\mathrm{n}=6$ ). 
To investigate the effects of iron on GM-CSF production by synovial fibroblasts, three different concentrations of ferric or sodium citrate $(0.01,0.1$, and $1 \mathrm{mmol} / \mathrm{l}$ at final concentration) were added to synovial fibroblast 96 hour culture with three different concentrations of $\operatorname{ILl} \beta(1,10$, and $100 \mathrm{ng} / \mathrm{ml}$ at final concentration). Ferric citrate ( $1 \mathrm{mmol} / \mathrm{l})$ but not sodium citrate significantly enhanced GM-CSF production by synovial fibroblasts on stimulation with $1 \mathrm{ng} / \mathrm{ml}$ of ILl $\beta$ (fig lA). Ferric citrate $(0.1 \mathrm{mmol} / \mathrm{l})$ enhanced GM-CSF production by synovial fibroblasts on stimulation with $10 \mathrm{ng} / \mathrm{ml}$ of ILl $\beta$ (fig $1 \mathrm{~B}$ ). Also, concentrations of 0.01 or $0.1 \mathrm{mmol} / \mathrm{l}$ ferric citrate enhanced production of GM-CSF by synovial fibroblasts on stimulation with $100 \mathrm{ng} / \mathrm{ml}$ of ILl $\beta$ ( fig lC). However, ferric citrate at any concentration tested did not enhance IL6 or IL8 production by synovial fibroblasts on stimulation with any concentration of ILl $\beta$ including $100 \mathrm{ng} / \mathrm{ml}$ (data not shown).

To test whether iron regulates the transcriptional level of GM-CSF production by synovial fibroblasts on stimulation with IL1 $\beta$, GM-CSF, IL6 and IL8 mRNA expression in synovial fibroblasts were examined semiquantitatively by reverse transcriptase-polymerase chain reaction (RT-PCR). The method used for RT-PCR using specific primers for cytokines and glyceraldehyde-3-phosphate dehydrogenase as a control has been described in detail previously. ${ }^{5}$ The expression of mRNA encoding these cytokines in synovial fibroblasts was undetectable without ILl, and was dose dependent on ILl $\beta$ reaching a plateau after three hours in culture. Ferric citrate $(0.1 \mathrm{mmol} / \mathrm{l})$ significantly enhanced ILl induced GM-CSF mRNA expression in synovial fibroblasts but not that of IL6 or IL8 (data not shown).

GM-CSF is produced by T cells, macrophages, mast cells, endothelial cells, and fibroblasts in response to specific activating signals. GM-CSF gene expression is controlled by binding of transcription factors such as NF-GMa, NF-GMb, NF- $\mathrm{KB}$, Elf-1, NF-AT/APl complex, and Spl related complex to their specific promoter regions. ${ }^{6}$ It is unknown which transcription factors participate in the iron mediated regulation of ILl induced GM-CSF production by synovial fibroblasts. Dlaska and Weiss recently showed that iron regulates the transcription of inducible nitric oxide synthase (iNOS) of macrophage-like cells stimulated with interferon $\gamma$ (IFN $\gamma$ ) and/or lipopolysaccharide, and binding of NF-IL6 to its consensus motif within the iNOS promoter was reduced by iron and enhanced by an iron chelator. ${ }^{7}$ We found that iron enhanced ILl induced GM-CSF production by synovial fibroblasts. Taken together, the intracellular iron levels might control GM-CSF production induced by ILl by mechanism(s) similar to the action of ironresponsive element binding proteins on ferritin or transferrin receptor synthesis or iNOS induction. ${ }^{8}$
We found that the effects of iron on GM-CSF production induced by ILl were different from those on IL6 or IL8 production. Agro et al reported that $\mathrm{PGE}_{2}$ enhanced IL6 and IL8 but inhibited GM-CSF production by ILl stimulated synovial fibroblasts. ${ }^{9}$ Previously, we showed that iron decreased $\mathrm{PGE}_{2}$ production by synovial fibroblasts. ${ }^{3}$ Iron might enhance GM-CSF production through down regulation of $\mathrm{PGE}_{2}$ production. Yoshida et al found that gold compounds and divalent metal ions inhibited induction of IL6 and IL8 but not production of GM-CSF by ILl induced synovial fibroblasts through inhibition of NF- $\mathrm{\kappa B}$ binding to DNA. ${ }^{10}$ Thus, there may be different signal transduction pathways among these three cytokines in ILl stimulated human synovial fibroblasts.

\section{Authors' affiliations}

K Nishiya, H Wang, K Tahara, K Hashimoto, Second Department of Internal Medicine, Kochi Medical School, Nankoku City, Kochi 783-8505 Japan

Correspondence to: Professor K Nishiya, Nishiya Naika, 5-20, Honmachi, Fukuyama City 720-0056 Japan;

nishiya@fukuyama.hiroshima.med.or.jp

Accepted 2 May 2002

\section{REFERENCES}

1 Fritz P, Saal JG, Wicherek C, Konig A, Laschner W, Rautenstrauch H. Quantitative photometrical assessment of iron deposits in synovial membranes in different joint diseases. Rheumatol Int 1996;15:211-16.

2 Nishiya K. Stimulation of human synovial cell DNA synthesis by iron. J Rheumatol 1994:21:1802-7.

3 Hisakawa N, Nishiya K, Tahara K, Matsumori A, Hashimoto K. Down regulation by iron of prostaglandin E2 production by human synovial fibroblasts. Ann Rheum Dis 1998;57:742-6.

4 Yang YH, Hamilton JA. Dependence of interleukin-1-induced arthritis on granulocyte-macrophage colony-stimulating factor. Arthritis Rheum 2001:44:111-19.

5 Nagano I, Takao T, Nanamiya W, Hashimoto K. Modulation of type interleukin-1 receptor messenger RNA followed by one and repeated endotoxin treatment in the mouse. J Neuroimmunol 2000; 105:154-60.

6 Musso M, Ghiorzo P, Fiorentini P, Giuffrida R, Ciotti P, Garre C, et al. An upstream positive regulatory element in human GM-CSF promotor is recognized by NF-kB/Rel family members. Biochem Biophys Res Commun 1996;223:64-72

7 Dlaska $M$, Weiss G. Central role of transcription factor NF-IL6 for cytokine and iron-mediated regulation of murine inducible nitric oxide synthase expression. J Immunol 1999:162:6171-7.

8 Weiss G, Werner-Felmayer G, Werner ER, Grunewald K, Wachter $\mathrm{H}_{\text {, }}$ Hentze MW. Iron regulates nitric oxide synthase activity by controlling nuclear transcription. J Exp Med 1994; 180:969-76.

9 Agro A, Langdon C, Smith F, Richards CD. Prostaglandin E2 enhances interleukin 8 (IL-8) and IL-6 but inhibits GMCSF production by IL-1 stimulated human synovial fibroblasts in vitro. J Rheumatol 1996;23:862-8.

10 Yoshida S, Kato T, Sakurada S, Kurono C, Yang JP, Matsui N, et al. Inhibition of IL-6 and IL-8 induction from cultured rheumatoid synovia fibroblasts by treatment with aurothioglucose. Int Immunol 1999;11:151-8.

\title{
Clinical analysis of gouty patients with normouricaemia at diagnosis
}

\author{
Y-B Park, Y-S Park, S-C Lee, S-J Yoon, S-K Lee
}

Ann Rheum Dis 2003;62:90-92

G outy attacks usually occur in patients with hyperuricaemia, but patients with gout who have normouricaemia are believed to be in the minority. ${ }^{12}$ This is a common conception about gout because monosodium urate crystals are formed at blood concentrations of uric acid over $420 \mu \mathrm{mol} / \mathrm{l}$ at a body temperature of $37^{\circ} \mathrm{C}$. $^{3}$ Recently, two studies showed that the incidence of gouty attacks in normouricaemia was as high as $39-43 \%,{ }^{45}$ which is much higher than our traditional view. ${ }^{1-3}$ However, few data on normouricaemia in gout have been reported so far. ${ }^{6-8}$ The prevalence of patients with gout who have normouricaemia at diagnosis has not yet been determined, and even their clinical characteristics and laboratory findings have not been reported. 
Table 1 Comparison of the clinical and laboratory variables of normouricaemic gout and hyperuricaemic gout at diagnosis

\begin{tabular}{|c|c|c|c|}
\hline & $\begin{array}{l}\text { Normouricaemic } \\
\text { gout }(n=27)\end{array}$ & $\begin{array}{l}\text { Hyperuricaemic } \\
\text { gout }(n=81)^{*}\end{array}$ & $\mathrm{p}$ Value \\
\hline \multicolumn{4}{|l|}{ Demographics } \\
\hline Age (years) & $60.6(13.9)$ & $54.2(11.8)$ & 0.02 \\
\hline First symptom to diagnosis (months) & $32.2(36.3)$ & $54.2(66.3)$ & 0.03 \\
\hline BMI $\left(\mathrm{kg} / \mathrm{m}^{2}\right)$ & $23.8(2.9)$ & $23.1(3.3)$ & NS \\
\hline \multicolumn{4}{|l|}{ Associated conditions } \\
\hline Hypertension & 15 & 40 & NS \\
\hline Renal insufficiency $\uparrow$ & 5 & 28 & NS \\
\hline Heavy alcoholic intake & 5 & 9 & NS \\
\hline Diabetes mellitus & 2 & 11 & NS \\
\hline Precipitating events $\ddagger$ & 11 & 35 & NS \\
\hline Associated diseases $\S$ & 12 & 30 & NS \\
\hline \multicolumn{4}{|l|}{ Articular involvement } \\
\hline First MTP & 19 & 57 & NS \\
\hline Upper extremities & 1 & 15 & NS \\
\hline Lower extremities & 27 & 76 & NS \\
\hline Polyarticular involvement $\Phi$ & 11 & 45 & NS \\
\hline Documented tophi & 4 & 36 & 0.006 \\
\hline Serum uric acid ( $\mu \mathrm{mol} / \mathrm{l})$ & $320(80)$ & $550(90)$ & $<0.001$ \\
\hline 24 Hour urinary uric acid excretion $(\mathrm{mmol} /$ day) & $4(1)$ & $4(5)$ & NS \\
\hline BUN (mmol/l) & $5.5(2.0)$ & $7.5(1.5)$ & 0.02 \\
\hline Creatinine $(\mu \mathrm{mol} / \mathrm{l})$ & $100(30)$ & $140(110)$ & 0.002 \\
\hline \multicolumn{4}{|c|}{$\begin{array}{l}\text { BMI, body mass index; MTP, metatarsophalangeal joint; NS, not significant; BUN, blood urea nitrogen. } \\
\text { *Patients with hyperuricaemia were randomly selected from the study group using a table of random } \\
\text { sampling; trenal insufficiency was defined as a serum creatinine level above } 130 \mu \mathrm{mol} / \mathrm{l} \text { or a creatinine } \\
\text { clearance below } 1.00 \mathrm{ml} / \mathrm{s} \text {; łprecipitating events for an acute attack of gout are binge drinking, meat, } \\
\text { surgery, infection, trauma, physical stress, and deterioration of underlying medical disease; §associated } \\
\text { diseases are acute renal failure, chronic renal failure, renal transplantation, coronary artery occlusion } \\
\text { disease, heart failure, stroke, and pulmonary tuberculosis; Ipolyarticular involvement was defined as more } \\
\text { than one joint affected in a gouty attack. }\end{array}$} \\
\hline
\end{tabular}

We designed this study to determine the prevalence of normouricaemia in patients with gout at diagnosis, and to determine the natural course of normouricaemic gout and the differences between the clinical characteristics of patients with normouricaemic and hyperuricaemic gout at diagnosis.

We retrospectively reviewed 226 Korean patients who were newly diagnosed as having gout at the Severance Hospital, Yonsei University College of Medicine, Seoul, Korea, between January 1996 and May 2000. The diagnosis of gout was made during an acute attack of gouty arthritis and confirmed by either the presence of negatively birefringent needle shaped crystals or by satisfaction of the American College of Rheumatology criteria for gout. ${ }^{9}$ Normouricaemia is defined as serum uric acid below 420 $\mu \mathrm{mol} / \mathrm{l}$ in men and $360 \mu \mathrm{mol} / \mathrm{l}$ in women. ${ }^{10}$ Patients taking urate lowering agents (allopurinol, probenecid) were excluded. Serum uric acid was determined in samples drawn when a gouty attack occurred at diagnosis by the uricase enzyme method.

Among the 226 gouty patients, 27 (12\%) male patients showed normouricaemia at diagnosis. Table 1 summarises the

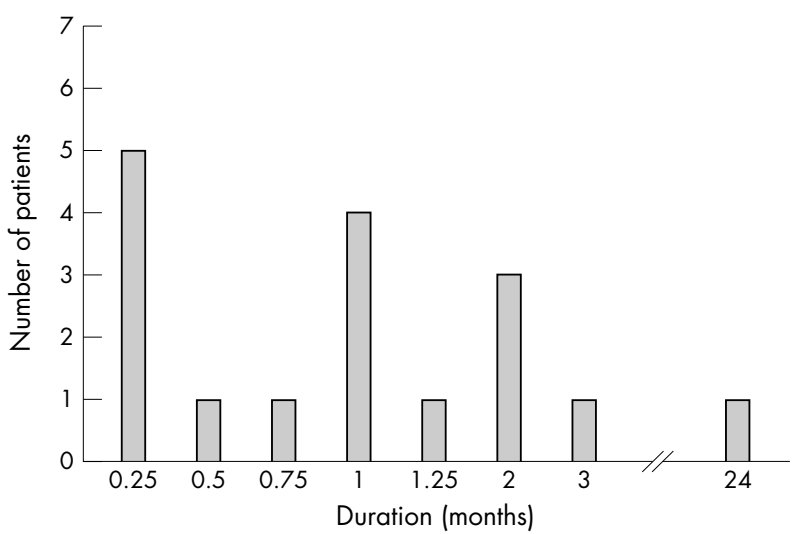

Figure 1 Time from the diagnosis of gout to the development of hyperuricaemia. clinical characteristics of the patients. Twenty one of 27 gouty patients with normouricaemia were followed up; among these patients, 17 patients $(81 \%)$ developed hyperuricaemia at a median of one month after diagnosis (range: one week to 24 months) (fig 1), and only four patients (19\%) still showed normouricaemia. These four patients were followed up at $11,25,28$, and 34 months respectively, but showed no more gouty attacks. All these patients had gout proved by the presence of crystals and also had normouricaemia before diagnosis.

The mean age at diagnosis was higher in gouty patients with normouricaemia than in patients with hyperuricaemia, whereas the duration from the first symptom to diagnosis, and the prevalence of documented tophi, was higher in gouty patients with hyperuricaemia. Serum uric acid, blood urea nitrogen, and creatinine levels were lower in gouty patients with normouricaemia (table 1 ).

We found that 27/226 ( $12 \%$ ) of gouty patients at diagnosis had normouricaemia, which was a lower incidence than found in the two reports mentioned previously. ${ }^{45}$ The discrepancy between our results and the results of those studies may be because the previous studies analysed the incidence of gouty patients with normouricaemia at the time of any acute attack, ${ }^{45}$ whereas we analysed the incidence at the time of diagnosis.

Seventeen of $21(81 \%)$ gouty patients with normouricaemia at diagnosis subsequently became hyperuricaemic. The median time for progression from normouricaemia to hyperuricaemia was one month. Our results corresponded with those of previous reports which showed that serum uric acid usually fell during an acute attack and rose during the interim. ${ }^{45}$ Only four gouty patients with normouricaemia at diagnosis continued to have normouricaemia. This "genuine" normouricaemic gout was present in only a small proportion, and these patients followed a mild disease course without secondary attack.

These observations may help a doctor to decide whether a diagnosis of gout can be made when normouricaemia is present and may help in predicting the disease course of normouricaemic gout at diagnosis. 


\section{Authors' affiliations}

Y-B Park, Y-S Park, S-C Lee, S-J Yoon, S-K Lee, Division of Rheumatology, Department of Internal Medicine, Institute for Immunology and Immunological Disease, BK 21 Project for Medical Sciences, Yonsei University College of Medicine, Seoul, Korea

Correspondence to: Dr S-K Lee, Division of Rheumatology, Department of Internal Medicine, Yonsei University College of Medicine, Shinchondong

134, Seodaemoongu, Seoul, South Korea 120-752

sookonlee@yumc.yonsei.ac.kr

Accepted 17 May 2002

\section{REFERENCES}

1 Weinberger A. Gout, uric acid metabolism, and crystal-induced inflammation. Curr Opin Rheumatol 1995;7:359-63.
2 Snaith ML. Gout, hyperuricemia, and crystal arthritis. BMJ 1995;310:1521-5.

3 Seegmiller JE. The acute attack of gouty arthritis. Arthritis Rheum 1965;8:714-23.

4 Logan JA, Morrison E, McGill PE. Serum uric acid in acute gout. Ann Rheum Dis 1997;56:696-7.

5 Schlesinger N, Baker DG, Schumacher HR Jr. Serum urate during bouts of acute gouty arthritis. J Rheumatol 1997;24:2265-6.

6 Snaith ML, Coomes EN. Gout with normal serum urate concentration. BM 1977;i:686-7

7 Hadler N, Frank WA, Bress N, Robinson DR. Polyarticular gout. Am J Med 1976:56:715-19.

8 McCarty DJ. Gout without hyperuricemia. JAMA 1994;4:302-3.

9 Wallace SL, Robinson H, Masi AT, Decker JL, McCarty DJ, Yu T-F. Preliminary criteria for the classification of the acute arthritis of primary gout. Arthritis Rheum 1977;20:895-900.

10 Cohen MG, Emmerson BT. Gout. In: Klippel JH, Dieppe PA, eds. Rheumatology. 2nd ed. London: Mosby; 1998:8:14.1.

\title{
HLA-DRB $1{ }^{*} 03$ and DQB 1 *0302 associations in a subset of patients severely affected with systemic lupus erythematosus from western India
}

\author{
U Shankarkumar, K Ghosh, S S Badakere, D Mohanty
}

Ann Rheum Dis 2003;62:92-93

G netic factors are likely to be important both in determining the overall susceptibility to systemic lupus erythematosus (SLE) and in influencing the remarkable clinical heterogeneity in disease expression found in affected subjects. The more common clinical features seen in patients with SLE include, skin and joint diseases, renal disease, neuropsychiatric complications, and also some haematological abnormalities. Genetic factors, together with environmental factors, strongly influence the development of SLE. Multiple loci within the major histocompatibility complex (MHC) have been implicated in susceptibility as have HLA class II alleles, complement components, and tumour necrosis factor (TNF) loci.

Currently it is believed that some HLA alleles are in genetic linkage disequilibrium with certain disease related genes and they regulate the immune responses. Since 1969, when the first case of SLE was reported from India, the disease has been extensively studied in different regions of the country-

Table 1 HLA alleles associated with severe SLE

\begin{tabular}{|c|c|c|c|c|c|}
\hline HLA & $\begin{array}{l}\text { Patients } \\
\text { (\%PF) } \\
(n=53)\end{array}$ & $\begin{array}{l}\text { Controls } \\
(\% \mathrm{PF}) \\
(\mathrm{n}=110)\end{array}$ & OR & $\mathrm{p}$ Value & $\mathrm{Cl}$ \\
\hline $\mathrm{Al}$ & 39.60 & 1780 & 2.99 & $<0.001$ & 1.06 to 2.08 \\
\hline & & & & & \\
\hline A19 & & & & & \\
\hline B15 & & & 0.1 & $<0.001$ & 5.07 to 7.23 \\
\hline B27 & & & 5.40 & $<0.001$ & 1.42 to 2.54 \\
\hline DRB 1 * & & & & & \\
\hline 03 & S & & 9.67 & $<0.0001$ & 8.41 to 13.56 \\
\hline $14(6)$ & & & & & \\
\hline $\begin{array}{l}1001 \\
D Q B 1\end{array}$ & 6.30 & 30.00 & 0.21 & $<0.001$ & 1.84 to 2.34 \\
\hline 0302 & 56.30 & 10.00 & 8.02 & $<0.0001$ & $\begin{array}{l}12.88 \text { to } \\
18.45\end{array}$ \\
\hline 0203 & 12.50 & 50.00 & 0.17 & $<0.0001$ & 1.32 to 2.56 \\
\hline
\end{tabular}

$\% \mathrm{PF}$, percentage phenotype frequency; OR, odds ratio; $\mathrm{Cl}, 95 \%$ confidence interval. namely, Chennai, Calcutta, Mumbai, and New Delhi. A statistically significant clinical correlation comparing the clinical variables from other racial groups of the world has been reported in Indian patients with SLE. ${ }^{1}$ HLA association studies from Indian patients with SLE are considerably limited ${ }^{2}$ and, furthermore, varying interethnic differences in the associations have been reported from UK, South African and Icelandic populations.

\section{PATIENTS AND METHODS}

We studied 53 patients with severe SLE exhibiting the clinical manifestations described by the 1982 revised American Rheumatism Association diagnostic criteria who had one or more organ affected, such as kidney, brain, heart, and lungs. One hundred and ten normal healthy subjects with the same economic status and ethnic background comprised the controls for this study over the same period. The autoantibody profiles among the patients with SLE were studied by immunofluorescence and enzyme linked immunosorbent assay (ELISA). HLA-A and B locus antigens were identified by a National Institute of Health two stage microlymphocytotoxicity assay using indigenous and commercial antisera. The HLA-DRBl and HLA-DQBI alleles were determined by a polymerase chain reaction with sequence-specific primers technique from the total genomic DNA extracted from the EDTA blood. The phenotype frequencies, odds ratio, probability value, and confidence intervals were estimated using our database and computer programs. The $\mathrm{p}$ value was corrected by the Bonferoni inequality method.

\section{RESULTS AND DISCUSSION}

A significant increase in the frequency of HLA-A1, A2, B27, $\mathrm{DRB}{ }^{*} 03, \mathrm{DQB1} 0302$, and $\mathrm{DQB1} * 0601$ was found among patients with SLE. HLA-A19, B15, DRB1*14(6), DRB1*1001, and $\mathrm{DQB1}{ }^{*} 0203$ were found to be decreased in the patient group compared with the controls (table 1). The high risk alleles $\mathrm{DRBI}^{*} 03$ and $\mathrm{DQB1}{ }^{*} 0302$ were then compared with the findings for other populations of the world (table 2). The 
Table 2 Comparison of HLA allele associations in patients with SLE from other populations of the world

\begin{tabular}{|c|c|c|c|c|}
\hline \multirow[b]{2}{*}{ Population } & \multicolumn{2}{|c|}{ Number studied } & \multirow{2}{*}{$\begin{array}{l}\text { HLA alleles } \\
\text { associated }\end{array}$} & \multirow{2}{*}{$\begin{array}{l}\text { Reference } \\
\text { Number }\end{array}$} \\
\hline & Patient & Controls & & \\
\hline Spanish & 85 & 186 & $\begin{array}{l}\text { DR3, } \\
\text { DQA } 1 \text { *0501 }\end{array}$ & 6 \\
\hline Canadian & 214 & 320 & DR3 & 7 \\
\hline White & 99 & 177 & $\mathrm{DRB} 1$ *0301 & 5 \\
\hline Malaysian & 56 & - & $\begin{array}{l}\text { DR2, } \\
\text { DQB 1 *0501 } \\
\text { DQB 1 *0601 }\end{array}$ & 11 \\
\hline Taiwanese & 34 & 200 & DRB 1602 & 9 \\
\hline European & 577 & - & $\begin{array}{l}\text { DRB 1 *0402, } 07 \\
\text { DQB 1*0302,0301 } \\
\text { DQA 1*0201 }\end{array}$ & 8 \\
\hline Mexican & 81 & 99 & $\mathrm{DRB} 1$ *0301 & 10 \\
\hline Western Indian & 53 & 110 & $\begin{array}{l}\mathrm{DRB} 1{ }^{*} 03 \\
\mathrm{DQB} 1 \text { *0302 }\end{array}$ & Present study \\
\hline
\end{tabular}

comparison strongly supported the importance of ethnic background and indicated that the relative importance of different genes may vary in different populations studied. One of the important observations was that the Indian patients with SLE with HLA-DRB1 ${ }^{*} 03$ association overlap with the Spanish, Canadian, white, and Mexican populations. However, the Malaysian and Taiwanese population, who are predominantly mongoloid race, showed a different HLA association. All the patients with severe SLE studied presented with a high titre of antinuclear factor, antihistone antibodies, and anti-Sm antibodies. Further, it was found that $54 \%$ of the patients were anti-dsDNA positive, $10 \%$ had anti- Ro/SS-A antibodies, $22 \%$ had anti-La/SS-B antibodies, $14 \%$ had both Ro SS-A and La SS-B antibodies.

In SLE multiple loci within the MHC have been implicated in susceptibility-like HLA class II alleles, complement components, and TNF loci. ${ }^{6-11}$ HLA-DR2 and DR3 are both known to be associated with SLE and inheritance of both DR2 and C4B null alleles confers a higher relative risk. HLA-DQ1 and DQ2 are also found to be associated with Ro, La, Sm, and dsDNA autoantibodies. The HLA-DR2, DQ1 haplotype associated with SLE has low TNF levels. ${ }^{4}$ A review based on the clinical and laboratory measurements in Indian patients with SLE showed a higher proportion of alopecia, renal lupus, oral ulcers, and neurological involvement, reaching statistically significant levels when compared with other racial groups. ${ }^{1}$ HLA studies from patients with SLE from northern India showed an appreciable risk of HLA-DR4 among the patients, and additionally, the haplotype B8-DR4 was often found in the patient group. ${ }^{2}$ However, HLA-DR3 and TNF promoter polymorphisms in the white patients with SLE were independently associated. ${ }^{5}$ Interethnic differences in the associations of TNF promoter polymorphism with SLE have also been reported from the UK, South Africa, and Iceland. ${ }^{5}$ One of the interesting observations ${ }^{12}$ was the increased incidence of renal side effects with disease modifying drug "auranofin" in patients with rheumatoid arthritis, who incidentally inherited DRB 1*0301, an allele linked strongly with SLE in his study as well as in ours. It may be relevant to mention here that the $\mathrm{DRBI}^{*} 0301$ allele is present in $6.7 \%$ of the normal population, hence they may also become susceptible to the nephrotoxic effect of these kind of drugs when they receive treatment for various disease conditions.

In conclusion our results show, firstly, a significant twofold increase in the odds ratio for the presence of HLA-DRB ${ }^{*} 03$, and DQB1*0302, alleles and, secondly, a significant twofold decrease in the odds ratio for the presence of HLA-A19, DRB1*14(6), DRB1*1001, and DQB1*0203 alleles among the western Indian patients with SLE. Finally, the association supports the importance of ethnic background and indicates that the relative importance of different genes may vary in different ethnic populations around the world.

Authors' affiliations

U Shankarkumar, K Ghosh, S S Badakere, D Mohanty, HLA

Department, Institute of Immunohaematology, 13th floor, KEM Hospital, Parel, Mumbai 400012, Maharastra, India

Correspondence to: Dr U Shankarkumar; shankarkumar16@hotmail.com

Accepted 17 May 2002

\section{REFERENCES}

1 Malaviya AN, Chandrasekaran AN, Kumar A, Shamar PN. Systemic lupus erythematosus in India. Lupus 1997;6:690-700.

2 Mehra NK, Pande I, Taneja V, Uppal SS, Saxena SP, Kumar A, et al. Major histocompatibility complex genes and susceptibility to systemic lupus erythematosus in northern India. Lupus 1993;2:313-14.

3 Steinsson K, Jonsdottir S, Arason GJ, Kristjandottir H, Fossdal R, Skaftadottir I, et al. A study of the association of HLA DR, DQ and complement $\mathrm{C} 4$ alleles in systemic lupus erythematosus in Iceland. Ann Rheum Dis 1998:57:503-5.

4 Rood MJ, van Krugten MV, Zanelli E, van der Linden MW, Keijsers V, Schreuder GM, et al. TNF - 308A and HLA DR3 alleles contribute independently to susceptibility to systemic lupus erythematosus. Arthritis Rheum 2000:43:129-34.

5 Tsuchiya N, Kawasaki A, Tsao BP, Komata T, Grossman JM, Tokunaga K. Analysis of the association of HLA DRB 1, TNF alpha promoter and TNFR2 (TNFRSF 1B) polymorphisms with SLE using transmission disequilibrium test. Genes Immun 2001;2:317-22.

6 Martin-Villa JM, Martinez-Laso J, Moreno-Pelayo MA, Castro-Panete MJ, Martinez-Quiles N, Alvarez M, et al. Differential contribution of HLA DR, $D Q$ and TAP2 alleles to systemic lupus erythematosus susceptibility in Spanish patients: role of TAP2*01 alleles in Ro autoantibody production. AnnRheum Dis 1998;57:214-19.

7 Gladman DD, Urowitz MB, Darlington GA. Disease expression and class II HLA antigens in systemic lupus erythematosus. Lupus 1999;8:466-70

8 Galeazzi M, Sebastiani GD, Tincani A, Piette JC, Allegri F, Morozzi G, et al. HLA class II alleles associations of anticardiolipin and anti-beta2GPI antibodies in a large series of European patients with systemic lupus erythematosus. Lupus 2000;9:47-55

9 Huang JL, Shaw CK, Lee A, Lee TD, Chou YH, Kuo ML. HLA DRB 1 antigens in Taiwanese patients with juvenile onset systemic lupus erythematosus. Rheumatol Int 2001;21:103-5.

10 Vargas-Alarcon G, Salgado N, Granados J, Gomez-Casado E, Martinez-Laso J, Alcocer-Varela J, et al. Class II allele and haplotype frequencies in Mexican systemic lupus erythematosus patients: the relevance of considering homologous chromosomes in determining susceptibility. Hum Immunol 2001;62:814-20.

11 Azizah MR, Ainoi SS, Kong NC, Normaznah Y, Rahim MN. HLA antigens in Malay patients with systemic lupus erythematosus: association with clinical and autoantibody expression. Korean J Intern Med $2001 ; 16: 123-31$

12 Gunnarsson I, Ringertz B, Bratt J, Sundelin B. HLA DRB 1 *0301 and $\mathrm{DQA1}$ *0501 in RA Ann Rheum Dis 2001;60:727. 